\title{
Strawberry cultivation: Horticultural Revolution in Meghalaya with reference to Sohliya and Mawpran Villages
}

\author{
Shailynti Lyngdoh \\ Department of Economics, Saint Mary's College, North Eastern Hill University, Shillong, Meghalaya, India
}

\begin{abstract}
The paper highlights the strawberry cultivation in Meghalaya a product of Horticultural Revolution in the state which was initiated by the technology Mission for the Integrated Development of Horticultural in the North eastern region and Government of Meghalaya where a Project of Centre of Excellence under Horticulture Departmental farm at Dewlieh was implemented. The pilot project had selected Sohliya village as a vibrant model for the cultivation of the crop. The success of the project had attracted other districts to cultivate the crop, where Mawpran village, in East Khasi Hills District is the next strawberry hub with all potentialities. The Revolution in strawberry cultivation has bring a major transformation in the socio-economic aspects of the people engaged in the cultivation of the crop and making Meghalaya the third largest producer of strawberry in the country,thus, provides an incentive for the development of other organic and traditional horticultural crops in the state.
\end{abstract}

Keywords: Development, Horticulture, Meghalaya, Mawpran, Revolution, Sohliya, Socio-economic, Strawberry.

\section{Introduction}

Strawberry is one of the most popular soft fruit and is cultivated in plains as well as in hills upto an elevation of 3000 metres in humid or dry regions, widely grown under protected and open condition in temperate and subtropical countries with maximum temperature of $22^{\circ}-25^{\circ} \mathrm{C}$ in the day and $7^{\circ}-13^{\circ} \mathrm{C}$ at night. Among all the different types of berries, strawberry gives the quickest return in a shortest possible period.

Strawberry is found in different parts of the world and this heart-shaped fruit of love had been mentioned by the Roman Poets Virgil and Ovid in the first century and in England gardeners had cultivated strawberries since the sixteenth century (Boriss et.al 2006).

Over the last few years, strawberries have experience one of the highest rate of consumption growth, where it is the highest consumed fresh fruits, rich in proteins, minerals $\mathrm{Ca}, \mathrm{P}$ and $\mathrm{K}$, fair source of Vit -A, B1, $\mathrm{B} 2$, niacin and Vit $-\mathrm{C}$ and it is regarded as one of the best natural sources of antioxidant. Besides, strawberry can be processed for making wine, jam, jelly, ice cream and soft drinks etc.

The United States is the world's largest producer of strawberry where most of the strawberry industries are located in California. United States produces almost 28 percent of the world supply. According to Food and Agricultural Organization of the United Nations (FAO), Spain accounted for 8 percent, followed by Russia, Korea, Japan and Poland accounting for 5 or 6 percent each. (Boriss et.al 2006).

Although the United States is the largest producer of strawberry in the world, its domestic demand is so high that in 2004 Spain came first as the largest exporter of strawberry in the world and United States ranked second. (Boriss et.al 2006).

In India, strawberry is confined only to the Hilly Tracts of Himachal Pradesh, Uttaranchal, parts of Uttar Pradesh and Kashmir valley. However, its cultivation has spread to tropical and subtropical zones, where other states like Meghalaya, Sikkim and Mizoram have taken up the cultivation of this viable fruit. So far, Maharashtra is the leading state in the production of strawberry.

\section{Horticultural Profile in North East India and Meghalaya:}

North Eastern Region has a vast potential for the development of horticulture sector. The climate and ecological conditions are most congenial for the cultivation of varieties of horticultural crops ranging from different types of fruits, spices, flowers, medicinal plants and wide variety of vegetables as shown in Table $1,2,3$.

The horticulture sector contributes 29.5 percent to GDP of the country originating from 8.5 percent of the cultivated land. The horticulture sector in North East India has emerged as economically rewarding and most viable option in the diversification of agriculture in today's time.(Bhattarcharjee 2013) 
Table 1. Diversity of major crops in North- East India.

\begin{tabular}{|l|l|l|}
\hline Crops & Estimated diversities & Diversities collected till 2000 \\
\hline Taros & 300 & 272 \\
\hline Yams & 230 & 200 \\
\hline Citrus & 17 spp. +52 vars. & 80 \\
\hline Banana & 16 species & 120 \\
\hline Orchids & 700 species & 15 \\
\hline
\end{tabular}

Source: Hore (2001), Asati \& Yadav (2004).

Table 2. List of major fruit diversities in North East India.

\begin{tabular}{|c|c|c|c|c|}
\hline $\begin{array}{l}\text { Common } \\
\text { name }\end{array}$ & Species & $\begin{array}{l}\text { No of } \\
\text { cultivars in } \\
\text { the region }\end{array}$ & $\begin{array}{l}\text { No. of wild } \\
\text { relatives } \\
\text { (approx) }\end{array}$ & Distribution \\
\hline \multicolumn{5}{|l|}{ Tropical } \\
\hline Mango & Mangifera indica L. & 25 & 2 & $\begin{array}{l}\text { Tropical areas of Assam, Meghalaya, } \\
\text { Mizoram ,Tripura }\end{array}$ \\
\hline Ber & Zizyphus mauritiana Lamk & 8 & 3 & Plains and Hills upto $500 \mathrm{~m}$ \\
\hline Pineapple & Ananas comosus L. & 7 & - & $\begin{array}{l}\text { Introduced and naturalized in the region. } \\
\text { Jaldhup and Lakhat type pineapple found } \\
\text { in Assam }\end{array}$ \\
\hline Aonla & Emblica officinalis Gaertn & 5 & 2 & $\begin{array}{l}\text { Star aonla found in Mizoram and round } \\
\text { aonla found in all states of north east }\end{array}$ \\
\hline Guava & Psidium guajava L. & 7 & 1 & $\begin{array}{l}\text { Tropical and subtropical (upto 1000m) } \\
\text { zone of India }\end{array}$ \\
\hline Banana & $\begin{array}{l}\text { Musa acuminate Colla } \\
\text { Musa balbisiana Colla }\end{array}$ & $\begin{array}{l}50 \\
1\end{array}$ & $\begin{array}{l}14 \\
3\end{array}$ & $\begin{array}{l}\text { Throughout the tropical and subtropical } \\
\text { zones of the country }\end{array}$ \\
\hline \multicolumn{5}{|l|}{ Subtropical } \\
\hline $\begin{array}{l}\text { Lime, } \\
\text { lemon \& } \\
\text { oranges }\end{array}$ & Citrus spp. & $\begin{array}{l}17 \text { plus their } \\
52 \text { vars. }\end{array}$ & - & $\begin{array}{l}\text { Lime and lemon in both tropical \& } \\
\text { subtropical while oranges in subtropical } \\
\text { zone. }\end{array}$ \\
\hline Peach & Prunus persica Benth \& Hook.f. & 7 & 3 & $\begin{array}{l}\text { Meghalaya, Nagaland and Arunachal } \\
\text { Pradesh }\end{array}$ \\
\hline Plum & Prunus domestica L. spp. institia (L) & 11 & & Meghalaya, Mizoram \\
\hline $\begin{array}{l}\text { Strawberr } \\
\mathrm{y}\end{array}$ & Fragaria vesca 1. & 3 & & Hills of NE region \\
\hline Apple & Malas sylvestris $(\mathrm{L})$ & 4 & 1 & $\begin{array}{l}\text { Arunachal Pradesh and introduced in } \\
\text { Nagaland }\end{array}$ \\
\hline
\end{tabular}

Source: Hore (2001), Asati \& Yadav (2004).

Table 3. Large diversities in vegetable crops- NE region.

\begin{tabular}{|l|l|}
\hline Indigenous & Eggplant, lablab bean, cucumber, smooth gourd, ridge gourd, snake gourd, sweet gourd \\
\hline Introduced & \\
\hline Ancient & Garden pea, onion, bottle gourd, cowpea, okra tec. \\
\hline Recent & Tomato, chilli, cauliflower, cabbage, French bean etc. \\
\hline
\end{tabular}

Source: Hore (2001), Asati \& Yadav (2004).

Meghalaya known as the "Abode of the Clouds" is well known for its organic horticultural fruits and vegetables. The total cropped area in Meghalaya during 2004-05 was 2, 65,874 hectares which is 11.85 percent of the total geographical area of 22.42 lakh Ha. The net cropped is 2, 19,224 Hectares, which is about 10 percent of the total geographical area. The total area under fruit crops is 26.23 thousand hectares. Among the fruit crops, the maximum area is under pineapple ( 9.5 thousand ha) followed by citrus ( 8.2 thousand ha) and banana ( 6.2 thousand ha). The total area under vegetable crops is 11.94 thousand hectares. As far as spices are concerned, Meghalaya is one of the leading States when it comes to ginger production ( 9.2 thousand ha) and also one of the leading producers of quality turmeric of a variety known as Lakadong, which has about 7 percent curcumin content. Arecanut and cashewnut are leading plantation crops followed by tea. The total area under plantation crops is 17.99 thousand hectares. (Eastern Panorama 2008)

The State's foray into high value low volume crops, of which strawberry is the prominent and successful introduction, has changed the economic landscape of the strawberry growers of Ri-Bhoi district. Other crops like rose, lileums, anthuriums, carnations, birds of paradise are also performing very well. During the last one year, high value vegetables like brocoli and colored capsicum have been introduced and marketed successfully. (Eastern Panorama 2008).

The Green Revolution that took place in the country in the late 1960's was largely confined to the North Western parts of the country and did not make much impact in the Eastern and North Eastern States. As far as India's North East Region is concerned, the growth in agro-horticulture has been slower and remains untapped ( Shukla 2005), ( Bhattacharjee 2013) 
Horticulture sector emerged as the most viable sector having potential for diversification of agricultural employment in rural areas, where variety of crops under different agro-climatic condition can be cultivated, thus enhancing good return on land generating employment and providing nutritious food. (Singh 2008), (Bhattacharjee 2013).

Generally, agricultural cultivation refers to cultivation of one primary crop in a certain plot of land. However, the advantage of horticultural crops is that it can be cultivated in a small plots of mixed crops, rather than large fields of single crop. Secondly, in Horticultural cultivation variety of crops ranging from fruits to vegetables can be cultivated simultaneously in a single plot of land (Christopher, 2005), ( Bhattacharjee 2013).

Horticulture in Meghalaya is heading for a drastic transformation as most of the horticultural crops have advantage over the traditional crops in generating rural employment, enhancing rural income and have high potentiality to tap national and international markets. Thus, the state government has a vision of transforming Meghalaya into a fruits and flowers state of the country by setting "Horti- hubs" in different districts of the state so as to harness horticultural crops and take them to a larger scale. Hence, making them more viable and productive.

\section{Objective:}

The paper tries to highlight how horticultural revolution in the state with reference to strawberry cultivation has made a drastic change in income, employment opportunities and on the overall socio-economic conditions of the people engaged in its cultivation.

\section{Methodology:}

The paper is based mostly on primary and secondary data. For primary data, direct interview method with the growers has been adopted. Besides, relevant informations have been gathered from government officials from Directorate of Horticulture, Govt of Meghalaya. As for secondary data, official records on strawberry cultivation from Horticulture Department and other related literatures like Government Documents, Newspapers, Journals and Articles etc have been availed.

\section{Revolution of Strawberry Cultivation:}

About 15 years ago strawberries where grown at a very small scale in Meghalaya. However, under the initiative of Technology Mission for the Integrated Development of Horticulture in the North eastern Region and Government of Meghalaya, Centre of Excellence which was conceived since 2004-2005 was implemented and in collaboration with Horticulture department farm in Dewlieh, in Umsning and active participation of the Ribhoi Strawberry Growers Association (RBSGA), Sohliya village located in Ribhoi district which is about $30 \mathrm{~km}$ from Shillong, is selected as a hub of strawberry cultivation in Meghalaya, endowed with climatic conditions conducive for their growth.

The success of Sohliya village as a strawberry hub in the state has provide a momentum to other districts to cultivate the crop, with East Khasi Hills leading the way by initiating a 2 hectares clustered cultivation of the crop in Mawpran village which is about $58 \mathrm{~km}$ from Shillong.

Initially, raw materials were brought from Maharashtra the number one state in strawberry cultivation but later seedlings and other technologies came all the way from California.

The Horticultural Revolution in strawberry cultivation has made Meghalaya the third largest producer of strawberry in the country after Maharashtra and Punjab. Meghalaya produces about 350 Metric tonnes of strawberry annually. The types of strawberry in the state are Camorosa, Sweet Charlie and Chandler.

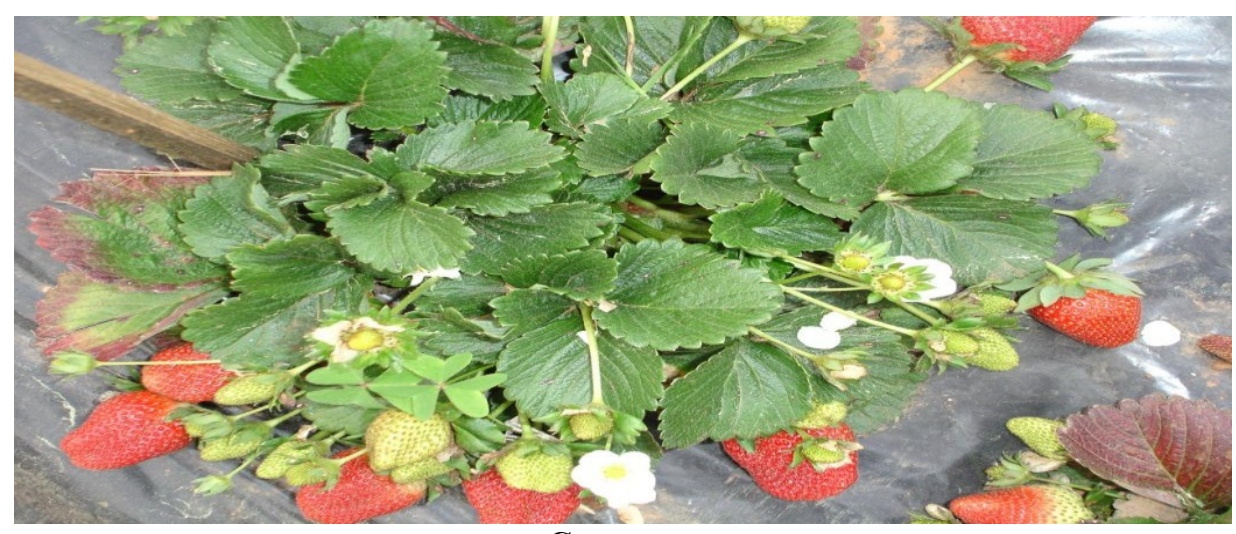

Camorosa 


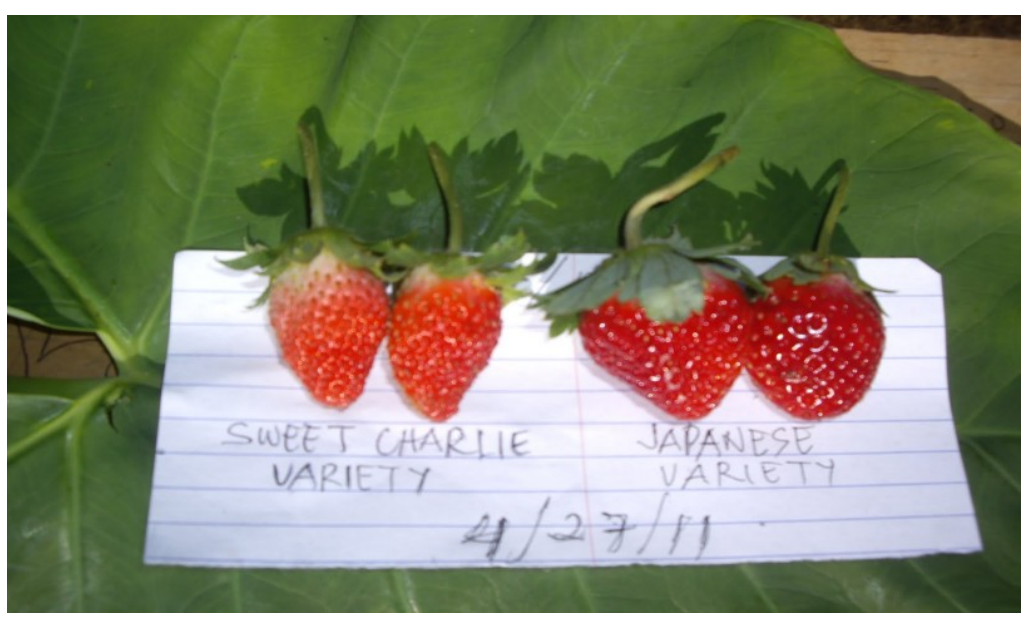

\section{Sweet Charlie}

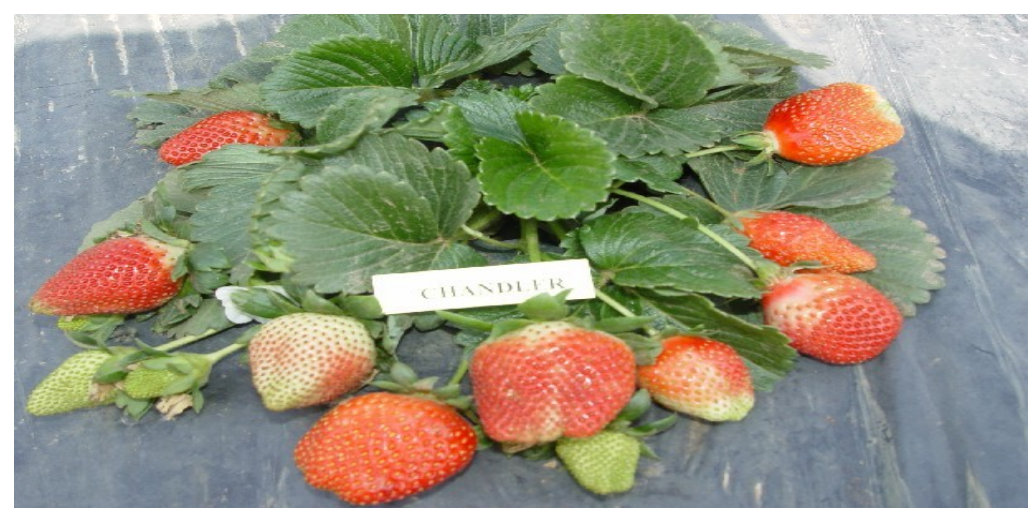

Chandler

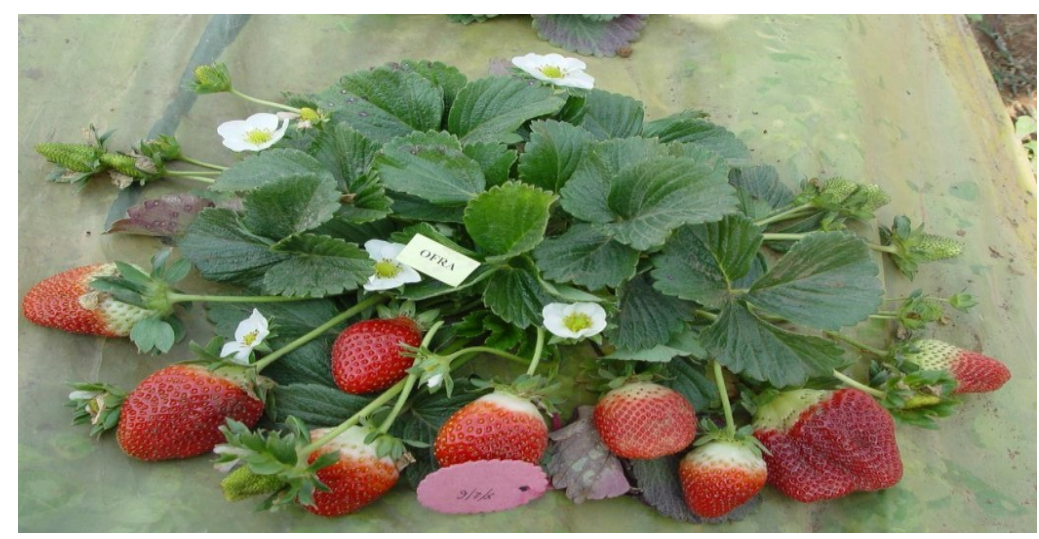

Ofra

In Sohliya the total production which was initially 125 Metric tonnes in 2009 had gone up to around 250-300 Metric tonnes annually in 2012-2013. Whereas, in Mawpran village, cultivation of the crop which was initiated only in 2008-2009, at present its total production is about 10-20 Metric tonnes annually.

The strawberries of Sohliya village are of high quality and are graded according to the size and categorized into A, B and C segments. The farm price of each is Rs 120, Rs 110 and Rs 260 per $\mathrm{Kg}$.

The market price of Grade A ranges between Rs 300-Rs 350 per Kg and that of grade B Rs 240-Rs 260 per $\mathrm{Kg}$, were sold in different parts of North east as far as Delhi and Kolkata, they have also been exported to nearby countries like Nepal and Bangladesh. However, in Mawpran village, the market price is seasonal, during the peak seasons of January- March, the price of strawberry is Rs 350 per $\mathrm{Kg}$, whereas during April the prices come down to Rs 200- Rs 280 per Kg. The strawberry from Mawpran village are sold mainly to District Headquarter i.e in Shillong, Guwahati (Assam) and to other places in North east. 


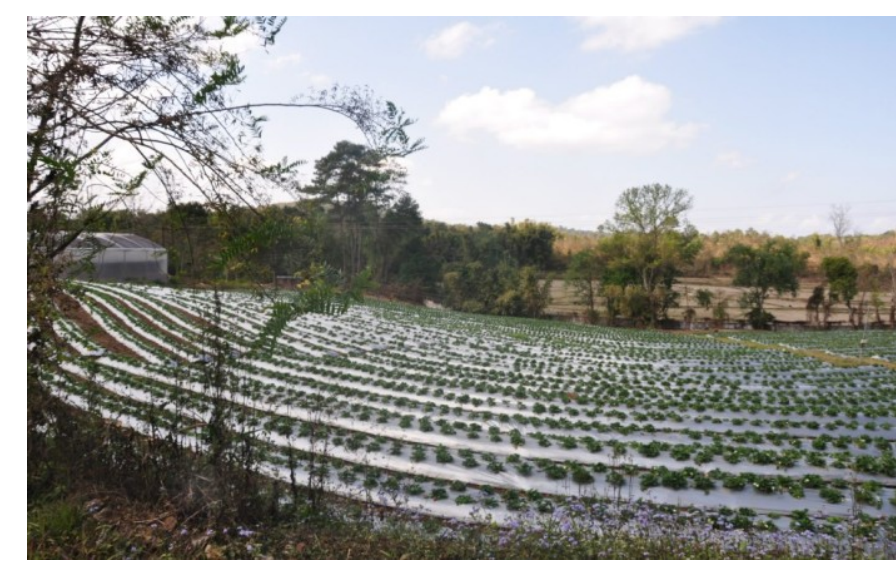

Sohliya

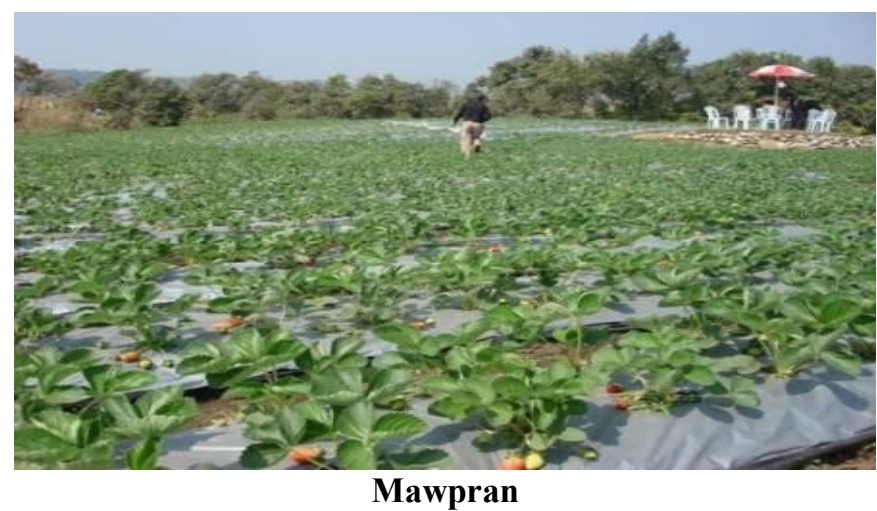

\section{Effects of Strawberry Cultivation:}

The Introduction of strawberry cultivation in Sohliya village has brought a massive transformation in the lives of the people in the village and adjoining areas. Sohliya a pretty village nestles in a lush green hills of Ribhoi districts, where in a decade back people were simple folks, agricultural labourers, toiling hard in their small patches of land with meager income and now by the advent of Strawberry cultivation, turns out to be the vibrant model of Horticultural Revolution and the originator of Meghalaya's Strawberry cultivation and the largest producer of strawberry in the state.

In conversation with Shri O. Lyngkhoi, general secretary of the Ribhoi Strawberry Growers Association (RBSGA), who happened to be a grower himself as well as the headman of Sohliya village, more informations were gathered on the socio-economic prosperity of the people in the village.

According to Lyngkhoi, about 66 out of the 67 households are engaged in the cultivation of strawberry ranging from one fourth acre to 3 acres of land. Earlier, the average weekly income of the villagers was of Rs 400 - Rs 500 but now has a massive jump by Rs $7000-$ Rs 9000 per week.

Strawberry cultivation in the village has open up employment opportunity where about 200-300 people get employment at a wage rate ranging from Rs 300- Rs 400 a day.

Sohliya village is now booming, where many families have been able to have TV sets, pucca houses, two wheelers and in some cases even cars. Even the village church has benefitted with Sunday collections now touching Rs 5000/- per week as compared to Rs 2000/- per week during the pre strawberry years. Besides, villagers have access to better schooling, health care facilities, banking facilities and finally overall improvement in their quality of life.

Besides, the inauguration of Rural Business hub (RBH) on $30^{\text {th }}$ January, 2010 in collaboration with Indian Institute of Entrepreneurship ( IIE) Guwahati and active cooperation of Ribhoi Strawberry Growers Association (RBSGA) a Horti-Eco Adventure Tourism project was launched, where eco friendly adventure tourism sporting activities like mountain biking, trekking and river rafting and as a result further diversify the job opportunities in the village.

Similar successes stories were witnessed from Mawpran village, though strawberry cultivation in the village had started just a few year back, but it is heading in the path of transformation and prosperity.

An interaction with Shri B. Shangpliang, General secretary of Strawberry Growers Association of Nongmadan Mawpran (SGANM), highlighted the diversification of employment in the Village, earlier villagers used to cultivate betel nuts and betel leaves, oranges and rearing bees for beehives but the economic prospects 
of strawberry cultivation has attracted many villagers to cultivate the crop and hence enhancing their average income. Many families have been able to send their children to better schools, colleges and for higher studies to District Headquarter or even to other states. Accessibility to better health care facilities and better nutritious food.

The farm currently provides employment to around 40-50 labourers with wage rate ranging from Rs 300- Rs 350 a day. Thus, Mawpran village is another strawberry hub in East Khasi Hills District and has a potential for the development of Eco Tourism as it is very close and just a few kilometers from Mawlynnong the Cleanest Village in Asia.

\section{Conclusion:}

Horticulture Revolution has brought a drastic change in the socio-economic conditions and quality of lives of many people directly and indirectly engaged in the cultivation of the crop and making Meghalaya the third largest producer of strawberry in the country. To sustain the initiative put forward by the Centre of Excellence at Dewlieh, Ribhoi District, concerted efforts and active participation by the growers and the state government are needed to enhance productivity and increase the scale of production by minimizing wastage of crop through adequate provision of proper storage facilities, development of food processing units which are horticultural based, equip growers with the latest and best technologies, improvement and availability of cheap transportation and lastly a proper mechanism to tap national as well as international markets.

The success of Horticulture Revolution in strawberry cultivation provides an incentive to the development of other organic and traditional horticultural crops of the state like ginger, turmeric, cashew nuts, pineapples, oranges and vegetables to a larger scale of production and productivity.

\section{References}

[1]. Annual report 2010-11. Horticulture Mission for North east and Himalayan States. http://sfacindia.com/Docs/SFAC Annual Report 2010 11.pdf.

[2]. Asati, B.S and Yadav, D.S. Diversity of Horticultural crops in North Eastern Region. ENVIS Bulletin Vol12(1) : Himalayan Ecology. 2004

[3]. Bhattacharjee, A. An Entrepreneurial analysis of the strawberry crop of Meghalaya. International Journal of Management Research and review. IJMRR/Nov 2013/ Volume 3/ Issue 11/ Article No-3/3719-3726. ISSN: 2249-7196. 2013

[4]. Boriss,H., Brunke,H. and Kreith, M.. Commodity Profile: Strawberries. Agricultural Marketing Resource center. Agricultural Issues Center University of California. Created March 2006.

[5]. Choudhury, R. Strawberry fields forever, in distant Meghalaya. Tehelka. 12 August. 2011.

[6]. Christopher, E.P. introductory Horticulture. Daya Publishing House, New Delhi. 2005

[7]. Department of Agriculture, Government of Meghlaya. Success story of Sohliya..

[8]. Eastern Panorama. Horticulture in Meghalaya. September 2008.

[9]. Goswami, R. Sohliya strawberries to shed California tag- Seeds germinated in hi-tech nursery in the village to cost $50 \%$ less \& ensure timely delivery. The Telegraph. Tuesday, September 7, 2010.

[10]. Govertment of Meghalaya. The Ribhoi portal. Ribhoi.gov.in. Strawberry in Ribhoi District.

[11]. Hore, D.K. North East India-A hot-spot for agrodiversity. Summer school on agriculture for hills and mountain ecosystem, pp 361 362. 2001

[12]. Kross, J.I. A Marketing Program for Strawberry Producers. Journal of farm Economics, Vol. 33, no .2 (May, 1951), pp. $242-248$.

[13]. Marbaniang, S.L. Colourful Berries. Meghalaya Times

[14]. Shukla, S.P. Commision Report@www.report. Govplanning.sc.in. 2007

[15]. Singh, A., Patel, R.K., Deshmukh, N.A., Lamare, R. and Deka, B.C. Strawberry packages of practices for cultivation in Meghalaya. Published by Director ICAR Research Complex for NEH Region, Umiam -793103, Meghalaya

[16]. Singh, B. Meghalaya taps US varsity to boost strawberry production. The Economic Times. 27 September 2007.

[17]. Singh, S.P and Nath, P. State of the Indian Farmer, Millenium Study, Volume 11: Horticulture Development, Mumbai. 2008.

[18]. Strawberry drives horticulture boom in Meghalaya. Forum. http://www.consumercourt.in/product-services/28591-strawberrydrives-horticulture-boom-meghalaya.html 